\title{
Anarchists, Marxists, and the New Left: Culture and Conflict in Students for a Democratic Society, 1960-1969
}

\author{
Adam Tomasi
}

In April 1967, Jack Smith, editor of the underground New York newspaper National Guardian, observed that Students for a Democratic Society (SDS), the preeminent organization of the American New Left, was "seeking fundamentally new answers to problems that the established American left has not been able to answer."1 SDS formulated new answers to the problems of social transformation until its dissolution at the 1969 convention in Chicago, when Marxist Progressive Labor (PL) was expelled by the Revolutionary Youth Movement (RYM), the forerunner of the Weathermen. ${ }^{2}$ This confrontation is well known, yet less frequently analyzed are the diverse ideological configurations produced by the civil rights and anti-war coalitions that galvanized SDS chapters in hundreds of campuses and cities. These coalitions, like the New Left in general, represented an uneasy alliance of radical political and countercultural energies; from this perspective, groups like PL may hardly be seen to have "infiltrated" SDS, as they were invited into the organization for strategic reasons.

Emphases on direct action, cultural dissent, and "participatory democracy" necessarily made SDS home to competing interpretations of the radical project. One of the most noteworthy, if understudied, of these was anarchism. The New Left's major project, globally, was the search for new answers to ongoing revolutionary questions by returning to-and reinventing-radical traditions from the past, such as anarchism. Scholars have observed that it is not useful for historians to draw distinctions between "social anarchism" a hard-political movement for a revolution that ends domination in all forms, and "lifestyle anarchism," which emphasizes personal change in service of creative, prefigurative politics; anarchists in the 1960s envisioned a bridge between radical lifestyles and the radical politics of the New Left. ${ }^{3}$ Early anarchists at the turn of the twentieth century, especially in the United States, affirmed values later adopted by the hippie counterculture of the 1960s: non-conformity, creative individuality, and mutual aid. ${ }^{4}$ Because there was a distinctive "anarchist counterculture," hard-political anarchists reviving past revolutionary action-forms could find natural affinities with the cultural revolution practiced by hippies. ${ }^{5}$ Countercultural anarchism in the 1960 s therefore had two manifestations: the 'dropouts' who found in anarchism an authentic political practice, and anarchists such as Murray Bookchin who attempted "bridge-building" between cultural and political revolutions. ${ }^{6}$ This essay argues that countercultural 
anarchism had a formative influence on SDS's evolution over time, because of anarchism and the counterculture's affinity with major trends in SDS and the New Left as a whole.

While organizational histories can overlook convergences between movement actors, SDS was at the centre of many concurrent ideological trends as a decentralized organization. SDS invited new-yet contradictory-answers to revolutionary dilemmas because it believed that participatory democracy, and the deliberation it necessitates, was not only the end of social transformation but the means of achieving it. Participatory democracy shaped the organization's earliest coalitions, and thus the uneasy inclusion of Marxists and Maoists with countercultural anarchists. While Marxists pushed SDS to adopt their own political lines, countercultural anarchists demanded participatory democracy to its fullest extent: total decentralization. Countercultural anarchists were represented by the "prairie power"7 chapters of students in the Midwest and Texas, and key non-student affiliates: Franklin and Penelope Rosemont, with Solidarity Bookshop in Chicago, and New York City's “affinity groups," Anarchos and Up Against the Wall Motherfucker. As the New Left looked to the past for new answers to old revolutionary dilemmas, anarchism was a natural fit, not only for its lineage from the nineteenth and early twentieth centuries, but also its resonance with countercultural politics. Scholars have argued for countercultural anarchism's significant role in 1960s movements to correct the exclusive scholarly attention on radical student movements. ${ }^{8}$ Yet if many students were not already countercultural anarchists, they found common purpose with non-student anarchists under the banner of SDS. This essay emphasizes this under-studied nexus within SDS not only for its integral role in many chapters' origins, but also for countercultural anarchism's addition of a dynamic layer to the New Left's disputes around doctrinaire Marxism and self-organization.

\section{Beyond the Campus: SDS, Civil Rights, and Anti-War Coalitions}

Before SDS demonstrated against the war in Vietnam, the organization fought for civil rights. In February 1960, four black college students staged a sit-in at a "whites only" lunch counter in Greensboro, North Carolina; months later, civil rights demonstrations swept Northern campuses. In May 1960, SDS responded to this wave of student activism with its first convention, on "Human Rights in the North," in Ann Arbor, Michigan. The convention was attended by organizers from the NAACP, Student Nonviolent Coordinating Committee (SNCC), and Congress of Racial Equality (CORE). . Tom Hayden, SDS's first civil rights "field reporter" and primary author of the Port Huron Statement, was inspired by SNCC volunteers such as Bob Moses to brave the arrests and beatings that civil rights demonstrators in Southern states were subjected to. ${ }^{10}$ SDS continued to build its base by uniting students already committed to civil rights, pacifism, or campus reform. ${ }^{11} \mathrm{Al}$ Haber, the first president of SDS, made connections at the National Student Association (NSA) during its 1961 convention in Madison, Wisconsin. NSA was filled with "stu- 
dent-government types... [who] stood politically somewhere to the right of Adlai Stevenson," yet many left-leaning students belonged to NSA because they lacked another political outlet; Haber found the latter cohort was sympathetic to the message of SDS. ${ }^{12}$ SDS also appealed to students in the Young People's Socialist League (YPSL). They were encouraged by YPSL mentors, such as Norman Thomas and Michael Harrington, to join SDS because a new, non-sectarian organization appeared unlikely - at the time - to devolve into factions. ${ }^{13}$ But the vast majority of students in SDS, prior to the group's signature "Port Huron Statement," were organizing for civil rights.

Anarchists shared the same values that would become defining features of the New Left and the counterculture. The central tenet of revolutionary anarchism is opposition to hierarchy and authority in all forms, particularly its manifestations in the state and in capitalism. The overlapping concerns of anarchists and the New Left have early origins in the late-nineteenth-century anarchists, immigrant and native-born, who agitated against the consolidation of state power and industrial capitalism in the United States. One of the most prominent was Emma Goldman, who emigrated to New York from Lithuania and published Mother Earth, an anarchist journal, from 1906 to 1917. Goldman, an anarcho-feminist, was arrested for promoting birth control in print, and during the First World War the federal government deported her to Russia for agitating for draft resistance. ${ }^{14}$ The global New Left in the 1960s was especially inspired by the memory of the Spanish Revolution of 1936, when anarchists battled Franco's fascist army, and workers collectively managed factories under the banner of the anarcho-syndicalist CNT, the Confederación Nacional del Trabajo. ${ }^{15}$ Anarchists in New York City, such as philosopher Murray Bookchin, were also committed to civil rights and participated in CORE demonstrations. ${ }^{16}$ Participation by anarchists in larger movements of the 1960 s was preceded by the growth of anarchist literary circles, pacifist groups, and journalist in the 1940s and 1950s. The "Contemporary Issues Group," organized by Bookchin, brought New York anarchists together to advocate for participatory democracy, the central ideal of the SDS Port Huron Statement, and a revolutionary alternative against liberal capitalism and state socialism during the Cold War. ${ }^{17}$ Foreshadowing the New Left preoccupation with authenticity, early anarchists adopted a "personalist" method which connected social revolution to changes in the practice of everyday life. Because anarchists opposed domination in all aspects, liberating interpersonal relationships was essential to an "anarchist counterculture" in the early twentieth century that spawned "free art, free schools, free media and free love."18 Bookchin, the anarchist theorist of "social ecology"- - harmony between humans and nature in a "post-scarcity society" — would become one of the most prominent anarchists of the 1960s, and founded the "East Side Anarchists" study group in 1962. This group brought civil rights activists, students, and artists together to read and discuss anarchist theory, which contributed to an intellectual climate in which the New Left was theorizing its own positions. ${ }^{19}$ 
The Port Huron Statement called for a coalition of liberal and socialist students, but its framework for decentralized organizing was the most salient overlap with anarchist thought. Participatory democracy entailed that people could take part in the decisions that affected their lives; indeed, SDS aspired for this autonomy both in society generally and the internal decision-making of its chapters. Anarchists such as Bookchin had also believed that "An anarchist society should be a decentralized society," as he argued in "Ecology and Revolutionary Thought" (1964), but SDS was not directly influenced by anarchist philosophy when drafting the Port Huron Statement. ${ }^{20}$ The largest influence on SDS's vision was the black-led SNCC, as SNCC organizers practiced decentralized, consensus-oriented decision-making when registering black voters in the South; Tom Hayden acknowledged that the democratic philosophy of Ella Baker was a key inspiration for the Port Huron Statement. ${ }^{21}$ Participatory democracy and decentralization were both fluid concepts that incorporated a wide spectrum of liberal and left perspectives; according to future SDS national secretary Greg Calvert, participatory democracy appealed to everyone "from radical democrats to anarchists and anarcho-syndicalists through democratic socialists and even some social democrats." ${ }^{22}$ Mark Rudd, a former SDS member and future "Weatherman," argues that for this reason there was a "strong anarchistic strain" in the vast majority of SDS chapters, despite geographic and cultural differences between campuses. ${ }^{23}$ Because the National Office did not have the resources to coordinate local chapters' activities, SDS was decentralized by necessity. ${ }^{24}$ But top-down coordination was unnecessary for SDS to grow as a national organization, from the widely-circulated Port Huron Statement and the energetic formation of chapters at different campuses.

The open-endedness of participatory democracy meant that while SDS benefitted from diverse perspectives, complex tensions in the organization's selfdefinition remained. The Port Huron Statement invited bottom-up input from chapters by its nature: in pamphlet form, the authors introduced it as a "living document" subject to critique, and described SDS as a forum for discussion, education, and debate. ${ }^{25}$ Neither was the organization exclusively wedded to students as the agents of change: non-students from faculty and affiliate groups were allowed to join SDS since its founding if they shared the same platform. SDS's original constitution, written in June 1962, established in Section 1 that "Membership is open to students, faculty and others who share the commitment of the organization to democracy as a means and as a social goal." Early members coalesced around restricting corporate power through regulations, ending the "military-industrial complex," nuclear disarmament between the United States and Soviet Union, and civil rights for African Americans. Yet surrounding the Port Huron Statement, before and after Tom Hayden and colleagues penned it together, was a difficult relationship to SDS's parent organization, the League for Industrial Democracy (LID). LID was staunchly reformist, pro-union, and anti-Communist; prior to 1960, SDS was the Student League for Industrial Democracy (SLID), LID's educational arm (or a glorified 
study group). LID allowed SLID, after much internal tension, to put grassroots civil rights activism above education-focused study groups, and change its name to SDS. ${ }^{26}$

SDS adopted from LID its dual opposition to the totalitarian Soviet Union and the attacks on civil liberties by Senator Joseph McCarthy and the House UnAmerican Activities Committee (HUAC). ${ }^{27}$ The Port Huron Statement argued that "The Communist Party has equated falsely the 'triumph of true socialism' with centralized bureaucracy"; the argument for a more authentic socialism was one of the central precepts of the New Left. ${ }^{28}$ Because SDS was an institution for "small-d" democrats, its 1962 constitution declared that "Advocates or apologists for such a [totalitarian] principle," meaning Stalinist apologia, "are not eligible for membership." ${ }^{29}$ The restrictive membership clause limited the bounds of who could participate in participatory democracy, but the limits were always contested; for example, SDS leaders Hayden and Al Haber were at odds with LID elders, such as former Socialist Party candidate Norman Thomas, for having a Communist Party member as a non-voting observer at a meeting. ${ }^{30}$ This eventually blew over, partly by Thomas's interventions, and SDS remained an affiliate of LID until 1965.

The Port Huron Statement catapulted SDS into becoming the flagship of the American New Left. Fittingly, the Port Huron Statement called for a "new left" that could radicalize liberals with institutional access and include socialists who understood the necessity for systemic change. SDS demanded that the Democratic Party cut ties with the segregationist "Dixiecrats" and that the United States and Russia end the Cold War through mutual disarmament. The Statement had also opposed corporate power and extreme income and wealth inequality, rejected state socialism, and believed in creating conditions for individuals to live authentically yet not egoistically. ${ }^{31}$ The Port Huron Statement's greatest impact on the student Left came from its call for a new vision of social transformation: "the message of our society is that there is no viable alternative to the present," a preview of the TINA ("there is no alternative") motto connected to the neoliberalism of Margaret Thatcher and Ronald Reagan in the 1980s. ${ }^{32}$ After Port Huron, SDS had a distinct identity beyond civil rights activism. The organization had also differentiated itself from "Old Left" activists who shied away from transformations of culture and "values," and others who uncritically supported the Soviet Union.

Although SDS opposed Soviet-style authoritarianism, Marxist groups could find common cause with SDS on the same platform that attracted anarchist allies: civil rights and anti-war activism. The Progressive Labor Party (hereafter PL), founded in July 1962 in New York at a meeting of fifty radicals from eleven cities, became the most prominent American Marxist party to march alongside, and later join, SDS. PL opposed Communist Party USA for supporting reformist trade union activity and the John F. Kennedy campaign, and criticized the Soviet Union for the "revisionism" characterized by Premier Khrushchev's "Secret Speech" that revealed Stalin's brutalities. Scholars often call PL a Maoist organization because it agreed with the Chinese Communist Party's thesis that Russia was capitulating to the West. ${ }^{33}$ 
However, while PL's members are remembered at SDS conventions for shouting quotations from Mao's Little Red Book, the PL platform's central demand was for a worker-student alliance, which intended to reclaim Marxism-Leninism with a vision for revolution that had the proletariat in the driver's seat. ${ }^{34}$ By embracing the Leninist model of "democratic centralism," which meant organizing through a vanguard party characterized by top-down leadership and disciplined commitment to the party's political line, PL set itself against decentralized participatory democracy. ${ }^{35}$ Despite this philosophical divide, PL shared with anarchists and members of SDS a strong support for the civil rights movement. For example, PL's Harlem centre, led by Bill Epton, an African-American Communist, focused on self-defense for black residents against police brutality. In 1964, PL participated in a riot against the police for murdering James Powell, a fifteen-year-old African-American boy; Epton was one of those charged with "criminal anarchy" for joining in disruptive events. ${ }^{36}$

The passage of the Civil Rights Act of 1964 meant that SDS lost one of its initial unifying causes, but the anti-Vietnam War movement became a new rallying point that brought New Left students, Marxists, and anarchists to the same demonstrations. As President Lyndon Johnson escalated American force and received Congressional support from the Tonkin Gulf Resolution, PL was ahead of SDS in mobilizing student demonstrations. On May 2, 1964, 1000 students marched in New York City to the United Nations building; 700 demonstrated in San Francisco, and smaller crowds appeared in Boston and Seattle. ${ }^{37}$ Some members of SDS helped plan the march, and the organization promoted it to chapters, but PL had been the first mover. After the march, PL founded a student group called the "May 2nd Movement" (M2M), based out of New York. M2M produced a publication called Free Student which denounced US intervention in Vietnam as imperialistic, and critiqued universities" devolution to a "factory education" model that invited corporate recruiters. ${ }^{38}$ However, the Movement's most crucial initiative was draft resistance, specifically its "We Won't Go" petition. Yet M2M, and PL more broadly, thought that Marxists could not isolate themselves from the emerging anti-war movement. ${ }^{39}$ The rallying cry of "We Won't Go" had an effect on SDS, as it prefigured the organization's shift a few years later to prioritizing draft resistance over more pacific strategies like teach-ins.

SDS's popularity as an anti-war organization was partially indebted to background efforts by the Progressive Labor Party. By September 1964, the SDS National Council noticed the growing presence of PL, and referred to it as "a strange and wonderful phenomenon." 40 The National Council had a whimsical attitude toward PL because movements such as M2M gave more students an anti-war consciousness, which led to a rapid increase in SDS chapters. Those students often preferred SDS because it was "free of the 'ideological hangups" of M2M."41 PL was not the prime mover of anti-war recruitment; the ultimate recruiter for the movement, Kirkpatrick Sale argues, was President Johnson-for calling up a substantial increase in draftees in February $1965 .^{42}$ 
Students for a Democratic Society's March on Washington against the war, in April 1965, brought together radicals of different persuasions as civil rights organizing had done previously. Countercultural anarchists contributed to the antiwar movement not only with more boots on the ground, but also through a distinctive tactic of street theater. On October 16, 1965, at a demonstration of 30,000 people in New York City, the countercultural anarchist Bread and Puppet Theater group held large effigies of a wrinkled, ape-like LBJ and the Virgin Mary with "Vietnam" around her neck. Bread and Puppet began in the Lower East Side in 1963, and conveyed a "spirit of pacifist anarchism" shared by another 1960s troupe from the Lower East Side, the Living Theatre of Judith Malina and Julian Beck. ${ }^{43}$ The SDS March on Washington was not as expressive, but it holds more currency in the history of the American peace movement. The march also revealed the tensions produced by SDS's attempt to create an ideological "big tent." At the march, 25,000 people heard speakers including SNCC organizer Bob Moses, historian Staughton Lynd, and then-president of SDS Paul Potter. Potter's speech sought to rally the ideologically and generationally diverse audience, most of whom did not belong to a peace organization. ${ }^{44}$ He argued that the war in Vietnam was rooted in a "deeper malaise," a system that simultaneously disenfranchised African Americans in the South, left millions in poverty, and denied autonomy for the South Vietnamese people. ${ }^{45}$

Despite Potter's New Left rhetoric about naming and challenging the totality, the march had a moderate demand: namely, to end the war. While some members of SDS, such as president Todd Gitlin, proposed draft resistance, and others argued for sending medical supplies to the Viet Cong, moderate members preferred a march to avoid the appearance of supporting the Communist government of Ho Chi Minh. ${ }^{46}$ The march organizers settled upon a simple demand to end the war in order to defer strategic debates such as these, and especially to leave open the question whether to advocate immediate withdrawal from Vietnam or negotiation with Hanoi. ${ }^{47}$ This was intended to bring many disparate voices into one demonstration, but LID's leaders were immensely critical of this move: they chastised SDS organizers for inviting "all those who agree," including Communists, that the war should end. ${ }^{48}$ This meant, in practice, that Progressive Labor and the W.E.B. Du Bois Clubs - the youth organization of Communist Party USA — could join the march, which cemented SDS's increasingly greater drift away from LID. SDS decided to relocate its National Office from New York, where LID operated, to Chicago, which prefigured the official breakup — and new connections with Marxist and anarchist factions - at the upcoming SDS convention in Kewadin, Michigan.

\section{Against the "Old Guard": The Countercultural Anarchism of "Prairie Power"}

In 1965, at a national convention in Kewadin, Michigan, SDS adopted a "non-exclusion" policy that welcomed organized Marxist parties into the organization. The 
policy was motivated by the same considerations that briefly led PL to found M2M: neither SDS nor PL wanted to isolate themselves from the broader anti-war movement. Still, their motivations to form an alliance were different in one critical sense: PL's unique goal was to pull SDS members toward its own political line, and PL's attendees at SDS conventions remained distinctly affiliated with the Party for that reason. Countercultural anarchists from a Midwest and Southwest contingent known as "prairie power" were crucial to the expansion of participatory democracy to include PL while staking out their own cultural-political alternative to the traditional prerogatives of the student New Left.

"Prairie power" was a neologism of Carl Davidson, SDS national vice president, who worked with students from chapters at the University of Oklahoma and the University of Texas-Austin to change the direction of the organization. ${ }^{49}$ The UT chapter had a surge in membership in the mid-sixties from Austin's counterculture, with people who "wore love beads [and] SDS buttons" together. ${ }^{50}$ Antiwar organizing, especially draft resistance, was the crucial rallying point that united hippies with the New Left and brought prairie power to SDS. But prairie power students were especially committed to decentralization in order to make SDS more relevant to each unique campus. Jeff Shero, another member of the UT SDS, argued at the 1966 convention in Clear Lake, Iowa that chapters should prioritize local connections with campuses and communities, above national visibility, "to reveal to people where they really are." 51 With this decentralist ethos, many participants in the Austin counterculture, such as Thorne Dreyer, publisher of the underground newspaper The Rag, were receptive to anarchistic ideas; in an interview with the Los Angeles Free Press in 1968, Dreyer exclaimed that The Rag was essentially connected to the "left-wing love, flowers, and freedom sect, anarchistic division of SDS." 52 And because prairie power opposed strict national guidelines for chapters, a stance consistent with decentralization, they could be counted on for votes against the non-exclusion policy despite their stark differences with PL.

SDS had pragmatic reasons to split from LID and create a big tent that included PL, but the organizational reset produced by the 1965 convention meant that SDS increasingly lost a core ideology or focal point for organizing. Because local SDS chapters often acted independently of the National Office, their chairs had not enforced the exclusion policy when members of PL dominated key chapters at Harvard, City College in New York, and San Francisco State. ${ }^{53}$ In 1965, PL dissolved M2M and told its cadres to join SDS in order to recruit new members for the Party. PL joined the majority of Kewadin convention-goers to vote for repealing the membership clause that excluded Communists. Chapters widely agreed that the restriction was a vestige of the Red Scare, although early SDSers already struck a balance between opposing the Red-baiting of the House Un-American Activities Committee (HUAC) and excluding advocates of any "totalitarian principle" in the SDS condition. ${ }^{54}$ New members rejected the undertones of the exclusion policy as a holdover of Red-baiting, but the shift to a non-exclusive membership policy meant 
that the new SDS triggered a fundamental break with the politics of LID, its ancestor. The split was inexorable, and SDS and LID agreed to separate in October 1965. ${ }^{55}$ To mark this separation, SDS had even rewritten their constitution's preamble. Originally naming "Communism and the domestic Right" as authoritarian, the preamble became a tautological statement about "a radical, democratic program whose methods embody the democratic vision." ${ }^{56}$ The muddled constitution reflected a larger shift by SDS from having a single vision at all, as members debated at Kewadin whether they should even focus on anti-war activity above domestic issues. The variety of its new members" priorities meant that SDS "withdrew from antiwar leadership" nationally, though the National Office promoted its program for draft resistance over the next few years. ${ }^{57} \mathrm{PL}$ especially became less invested in opposing US escalation of the Vietnam War the more its members believed that Vietnamese nationalism was a "bourgeois idea" that substituted national identity for class consciousness, a position that the Party officially adopted by January $1969 .{ }^{58}$

The prairie power chapters were even more at odds with Progressive Labor than the student New Leftists who originally embraced PL for its opposition to the draft. The most striking differences had to do with the counterculture, which was widely reflected in the styles worn by members of UT SDS, and most of the attendees; the clean-cut, tie-wearing PL students stuck out like sore thumbs. ${ }^{59}$ The countercultural style reinforced an anarchist orientation against oppressive authority, and the Austin students' aversion to the overly theoretical language of the Marxists meant they favoured "action and bodies-on-the-line" — consistent with the early anarchist ideal of "propaganda of the deed." ${ }^{\prime 60}$ Shero recalled that hippies and students dealing with "ambiguity and searching" about the American system had a hard time debating PL members on their interpretation of Marxist doctrine and what it suggested for the direction of SDS. ${ }^{61}$ Although most of the Texas students had never read Marx, prairie power survived because the contingent had confident representatives in figures like Davidson or Shero. Davidson shared with prairie power this firm belief in direct action, and would validate their prioritization of local campus issues, but he criticized student intellectuals and "hippies hangouts" for failing to organize students outside their niche. ${ }^{62} \mathrm{Al}$ Haber held similar concerns, and argued that excessive decentralization was unproductive for organizing and damaging to the coherence of SDS.

The 1966 SDS convention in Clear Lake, Iowa was largely a victory for prairie power and anarchism. By this point, SDS had dropped its official affiliation with LID, after its non-exclusionary membership policy went into effect. The convention was praised by right-wing libertarian Murray Rothbard, as the anarchists (wearing "I Hate the State" buttons) were unseating the "social Democratic Old Guard." " Some of that may have only happened in Rothbard's head, but the overlap between prairie power and anarchism was evident in a popular convention paper by Carl Davidson, "Toward A Student Syndicalist Movement." The national VP advocated for "student control" of universities. Indeed, by likening the university to 
a factory and the students to its workers, and demanding a version of "syndicalism," Davidson returned to the lineage of American anarcho-syndicalism, and its quintessential representation: the Industrial Workers of the World (IWW), also known as the Wobblies, in the late-nineteenth and early-twentieth centuries. ${ }^{64}$ The IWW combined anarchist and socialist principles to support "industrial democracy and workers' control, rather than... better wages and working conditions," as Davidson recalls the syndicalist unions that inspired his vision. The IWW led the 1912 "Bread and Roses" strike of immigrant textile workers in Lawrence, Massachusetts, but lost momentum when its leaders were deported or imprisoned and once the repressive political climate of the First World War began. ${ }^{65}$ Despite this decline, the IWW remained as a political entity with annual national conventions in Chicago, and its headquarters there would become a site for political-countercultural innovation in the 1960 s. ${ }^{66}$

Davidson held conflicted attitudes about the prairie power alliance he helped cultivate but his theory of "student syndicalism" was compatible with the counterculture's ideal of autonomy, and complimented the Texas and Midwest chapters' priorities around university reform. ${ }^{67}$ As a result of this alliance, Davidson was elected Vice President by Clear Lake attendees and another prairie power ally, Greg Calvert, was elected National Secretary at SDS's national council: both represented the "new SDS style," embedded as it were in the counterculture. ${ }^{68}$

\section{“Listen, Marxist!”: Rebel Worker, Black Mask, UAW/MF, and Anarchos}

Just as Carl Davidson reclaimed the lineage of the IWW for student syndicalism, countercultural anarchists blended Wobbly traditions of creativity and humour with radical artistic movements from the early twentieth century. Franklin and Penelope Rosemont, IWW members who founded the anarchist Solidarity Bookshop in Chicago, published the Rebel Worker journal from 1964 to 1967. The Rosemonts borrowed the name Rebel Worker from an old Wobbly journal in 1919, reviving past revolutionary forms - particularly the vision of the IWW in its prime- through print culture. ${ }^{69}$ The journal blended the old with the new by combining insights inspired by anarcho-syndicalism and Surrealism, the radical aesthetic movement founded by André Breton in the 1920 s. $^{70}$ Breton believed that subverting the ordinary meanings of objects, and interrogating binary oppositions between notions like work and play, could achieve a revolution of everyday life. ${ }^{71}$ In 1965 , the Rosemonts met Breton and his Surrealist group in France, and the libertarian socialist Solidarity group and anarchist Freedom Press in London. ${ }^{72}$ As countercultural anarchists, the Rebel Worker group's goal was, according to Franklin Rosemont, to "abolish wage-slavery and to smash the State-that is, to make total revolution, and to have lots of fun..."73 In March 1965, he wrote a pamphlet for Rebel Worker no. 3, entitled "Mods, Rockers and the Revolution," which argued for the centrality of rock \& roll to working-class culture and a rebellious, youthful sensibility. He concluded that working-class youth culture could be channeled towards a revolutionary 
movement, and that rock music was evidence that longings for liberation were "not confined to small, isolated bands of conscious, politically 'sophisticated' revolutionaries." 74 The Rebel Worker group hoped that new subcultures, which subverted mainstream habits and language, could enter the fold of an oppositional counterculture, with political and revolutionary implications.

The Rosemonts graduated from Chicago's Roosevelt University only two years before, and interacted there with the school's SDS chapter. Penelope Rosemont recalled that they thought "SDS was just a mushy student group" until the day they returned to campus, no longer as students, and tabled Solidarity Bookshop. A Roosevelt University official told them to pack up their table because they did not want "commie stuff" around while the Chicago Tribune was filming on campus. A member of SDS, Steve Baum, came to the Rosemonts' defense and said that if the two were kicked off campus, the Roosevelt University SDS chapter would stage an enormous sit-in. ${ }^{75}$ By the end of 1967 , Solidarity Bookshop joined other radicals from Chicago to create the Louis Lingg Memorial Chapter of SDS. Lingg was the youngest of eight anarchists convicted after Chicago's "Haymarket Affair" in 1886; before he could be executed, Lingg committed suicide with a dynamite cartridge in a cigar, smuggled by a friend into his jail cell. ${ }^{76}$ Solidarity Bookshop allied with SDS not only to join anti-war demonstrations that the National Office was planning in Chicago, but also to collaborate with SDS's printing press, Liberation Press. The original Solidarity Bookshop was condemned under urban renewal, but Liberation Press agreed to print Franklin Rosemont's first Surrealist book, The Morning of a Machine Gun, in 1968. Penelope Rosemont helped assemble and print the radical pamphlets that many chapters requested, and had also aided in publishing SDS's Radical America journal, founded by Paul Buhle in $1967 .^{77}$ The year before, SDS began publishing New Left Notes, a weekly radical newspaper. This steady stream of underground publications and pamphlets had been a significant component of SDS's activism and self-understanding.

Countercultural anarchists of New York's Lower East Side shared the unique revolutionary orientation of the Rebel Worker group. Young "dropouts" fled to the Lower East Side in the 1960s because of the cheap rent and social freedom; in short, they considered it the "anti-suburb," a far cry from the middle-class life of suburbs or college campuses. ${ }^{78}$ The young people there who were politicallyminded were influenced by an anarchist legacy, especially the provocative style of guerilla theatre. In 1966, the loosely-knit collective Black Mask was founded by Ben Morea, a young, radical artist who discovered anarchism from the Living Theatre. ${ }^{79}$ Morea and his artist cohort preferred confrontational protest over intellectualizing in study groups; although he joined Bookchin's study group, Morea regularly chastised the participants for divorcing theory from action. ${ }^{80}$ Still, Bookchin's influence on Black Mask was as significant as the Living Theatre. During a discussion between Morea, Bookchin, the intellectual Herbert Marcuse, and future Black Mask member Osha Neumann, Bookchin spoke romantically of the decentralized syndicates, or 
the aficionados de trabajos, during the Spanish Revolution in the late 1930s. Morea agreed with the concept, but he believed that the people he knew would only ever use an English phrase, "affinity group." ${ }^{\prime 1}$ Black Mask adopted the affinity group model, which meant that its form was decentralized and its content was spontaneous.

Black Mask had built upon, yet exceeded, the traditional concerns of anarchist collectives. One of those concerns was "mutual aid," or the voluntary, reciprocal exchange of resources, theorized by anarcho-communist Peter Kropotkin in 1902. Kropotkin analyzed the evolutionary psychology of humans and nonhuman animals to argue that social Darwinists' praise for selfish competition neglected societies' reliance on "mutual-support instincts" and "human solidarity" for their perpetuation. ${ }^{82}$ Black Mask practiced mutual aid by offering "crash pads" to squatters, and serving a largely Puerto Rican community through a "free store" and community meals outside of St. Marks Church. ${ }^{83}$ Black Mask went beyond mutual aid from its inception; its inaugural action was to shut down the Museum of Modern Art (MoMA) for one day to "destroy the museums," the demand made by the inaugural issue of Black Mask, their magazine. ${ }^{84}$ This protest action followed in the footsteps of the counterculture, for Black Mask argued that modern art was the product of a repressive, bourgeois culture that separated creative expression from everyday practice. MoMA nervously shut down on October 10, 1966, which gave Black Mask visibility, but the group had not "destroyed" the museum. This was the critique fraternally leveled by Louise Crowley, an anarchist from the West Coast who received the first issue of Black Mask by mail. Crowley argued that museums were irrelevant to the power structure, and Morea replied that artists needed to be "opening another front" in a total revolution of both culture and politics. ${ }^{85}$

Black Mask belonged to the underground press, but the group evolved to prioritize street theatre. Bookchin replaced the East Side Anarchists group with the Anarchos journal, articles from which were re-printed in the late 1960 s by SDS's New Left Notes. ${ }^{86}$ But Morea ended the Black Mask magazine after ten issues to prioritize moving "INTO THE STREETS." ${ }^{87}$ When the group made this shift, they engaged in street theatre to oppose the Vietnam War as an extension of a destructive American culture. In 1967, Black Mask-and a larger group of young people-carted garbage in front of a fountain at the Lincoln Center for the Performing Arts. A flyer written by Osha Neumann called the dumping a "culture exchange," of "garbage-for-garbage": America was turning Vietnam into garbage, and Black Mask returned the favour. The "exchange" was filmed by Newsreel, a New Left film collective from New York, in an eleven-minute documentary that featured young people drinking wine, loudly debating strategy, and playing music on the subway on their way to the Lincoln Center. ${ }^{88}$ The garbage exchange not only signaled a shift to street theatre, it also heralded a name change, becoming "Up Against the Wall Motherfucker.” Neumann's flyer was signed, "Up Against the Wall Motherfucker-and into a trash can," loosely based on a poem by black nationalist Amiri Baraka called 
"Black People" (1967). ${ }^{89}$ Once Black Mask became the Motherfuckers, they continued their brand of symbolic provocation as a non-student chapter of SDS.

When Up Against the Wall Motherfucker (UAW/MF) joined SDS in 1967, they simultaneously challenged New Left students and Progressive Labor. Both were enemies of the group: Neumann recalled that the Motherfuckers hoped to break the "moral callus" of SDS, likening its lack of militancy to a hard tissue around a (politically) fractured bone. ${ }^{90}$ Their objective was to awaken "the sedate halls of the academy" with "the disruptive style of the streets." 11 UAW/MF was similarly concerned about PL's rise in the ranks: Morea thought that with Progressive Labor "trying to take [SDS] over and control its direction," it was imperative that uncommitted students know there were "many ways they could go." course, Carl Davidson and prairie power were already proving for students that they had options, yet the Motherfuckers believed in their methods above all. While the Motherfuckers promoted the ways of "the streets," they created tension with the Anarchos group; Bookchin was displeased by the affinity group that now called itself a "street gang with an analysis." 93 Poet Allan Hoffman, one of Bookchin's students, joined Black Mask despite the elder anarchist's protestations that street theatre would "undermine serious organizations" and preclude more practical routes to building a revolution. ${ }^{94}$ Despite Bookchin's misgivings, he would follow the Motherfuckers into SDS because of his shared concern that Progressive Labor was dominating the organization, and his own goal of steering the counterculture toward social revolution. ${ }^{95}$

UAW/MF's zealousness, especially its "unprintable name," made influencing SDS a harder task. ${ }^{96}$ The editor of the University of Wisconsin-Madison's Daily Cardinal was almost fired for "indecent language" by printing the Motherfuckers" name in an article on the 1967 SDS convention at Michigan State. ${ }^{97}$ Some of UAW/MF's appeals were satirical and drew a largely positive reaction at conventions, likely because almost 90 percent of the membership, according to a 1967 report from Carl Davidson, was "rapidly moving into the hippy, Bobby Dylan syndrome." At a 1967 National Council meeting in Lexington, Kentucky, UAW/MF managed to pass an amendment to a resolution supporting the United Farm Workers' grape boycott. The amendment, "that SDS drink more wine and do less talking," surely got the support of that 90 percent of hippies that Davidson called the "shock troops" of SDS. ${ }^{9}$

UAW/MF's other displays were often a mix of violent rhetoric and machismo and these patterns reflected the fact of male dominance in the group. ${ }^{100}$ For an SDS regional meeting in New York on March 10, 1968, the Motherfuckers submitted a handwritten chapter report solely comprised of a poem, beginning with a recipe for a Molotov cocktail, and ended with a "recipe" for making white radicals: "three parts bullshit" and "one part hesitation." "This could not be expected to carry over well, just as Neumann could not have expected much from another provocation at the 1968 Michigan convention. While PL had an intense debate with 
New Left students, Neumann grabbed the microphone, pulled his pants down, and "with my penis flapping in the wind, I condemned intellectual masturbation."102 Neumann omitted one detail: according to the College Press Service, he also told "everybody in PL to go home for a good fuck before they talked anymore," another example of the Motherfuckers' aggressive machismo. ${ }^{103}$ That year, PL energetically promoted its new Worker-Student Alliance Caucus, and pointed to the events of that year's May in France, where workers and students took part in general strikes and occupations. PL's disciplined, ideological questioning at conventions often bewildered uncommitted students, yet it undeniably swayed many convention-goers with its "thoughtful politicking" for a program to build a worker-student alliance. ${ }^{104}$ UAW/MF's response, provocative as the last, was indoor street theatre: they “dressed one person up as 'Student,' another as 'Worker,' and joined them into a 'Worker Student Alliance' in an elaborate marriage ceremony."105 Although PL did not command majority support, the rest of the convention-goers were too disorganized to agree upon a single vision for SDS: the Motherfuckers' ability to keep on with their antics was a reflection of that chaos. ${ }^{106}$

The June 1969 SDS convention in Chicago represented the peak of the chaos, one that meant anarchists, communists, and New Left students could not maintain a unified whole. The Anarchos group tabled at the event alongside numerous other organizations, including PL, but the group that held the most sway was the Revolutionary Youth Movement (RYM). RYM was formed by SDS National Secretary Mike Klonsky as a Marxist-Leninist and anti-imperialist counter to PL. RYM's platform was distinct for its attempts to unite with Third World revolutionary movements, especially Ho Chi Minh and the National Liberation Front, and the Black Panther Party. ${ }^{107}$ Klonsky ran unopposed for secretary at the 1968 Michigan convention, until one of the Motherfuckers put a trash bin over his head while another declared, "I nominate this trash can for National Secretary." 108 Klonsky won his position, and Bernardine Dohrn — another RYM member-won un-opposed for Inter-organizational Secretary, but the trash bin received some votes. ${ }^{109}$ At the National Council meeting in Ann Arbor, Michigan in December 1968, Klonsky and PL clashed over the role of students in a working-class movement. Klonsky and Dohrn argued students were themselves workers and deserved a distinct movement, whereas PL argued students were separate from the working class but should ally with it. ${ }^{110}$ An RYM-oriented resolution narrowly passed at that National Council meeting, and Klonsky's platform became SDS's official line.

RYM and PL overpowered the anarchists in SDS, despite a last-minute push by Anarchos for decentralization. Anarchos, which reconstituted itself at SDS as the Radical Decentralist Project, handed out Bookchin's essay "Listen, Marxist!" which argued that Leninism was a "disease" that enabled vanguards to consolidate power and stunt the possibility for revolution. Anarchists, like PL, tried to interpret the "French May" in 1968 as a validation of their perspective; for example, Bookchin's essay argued that the "temporary action committees" of French workers 
and students were an excellent example of an affinity group. ${ }^{111}$ Anarchos advocated that SDS chapters become affinity groups in Bookchin's first resolution published under the auspices of the Radical Decentralist Project; the group ran out of print copies on the conference's first day alone. ${ }^{112}$ While the anarchists built a quick following, it was too late to save SDS even in a decentralized form. Dohrn called a vote to expel PL for their criticisms of the Black Panthers, and of black anti-colonial revolutions. PL opposed black nationalism as an obstacle to socialist revolution, and the presence of Black Panther leaders such as Huey Newton at the 1969 convention was opposed by the Party. ${ }^{113}$ In defense of the Panthers against PL, Dohrn implored delegates "to decide whether the racist PL was fit political company."114 600 delegates walked out of the convention with Dohrn. RYM subsequently became the Weather Underground, a small collective that attempted, yet failed, to bring urban guerilla warfare in America, and SDS dissolved.

SDS's commitment to participatory democracy drove the organization to be as all-inclusive as possible, but this openness meant that SDS lacked a core ideology and, as a result, could be overtaken by PL and RYM. Anarchist Paul Goodman diagnosed this tension in a 1968 essay for The New York Times Magazine called "The Black Flag of Anarchism," in which he argued that the New Left was failing to reconcile the rhetoric of participatory democracy with the growing appeal of vanguard parties. Goodman credits participatory democracy, "the essence of anarchist social order," for its prominence in the Port Huron Statement, and the efforts of radical students to oppose bureaucracy and practice solidarity and self-management. But he worried that Leninist parties would manipulate the "lively energy and moral fervor" of young students, and that talk of cadres sounded too much like deadening military discipline. ${ }^{115}$ With the internal contradiction between participatory democracy and the rhetoric of vanguards, the latter won out. In a 1968 position paper at the SDS national convention, Penn State SDS member Neil Buckley, who allied with Calvert and Davidson in the National Office against PL, argued that "this movement in general and SDS...is an element of the revolutionary vanguard painfully forming from the innards of America," and that SDS should prepare "cells," or study groups, for political education. ${ }^{116}$ Ironically, Buckley advocated for a vanguard model in order to consolidate power in the National Office and neutralize PL's foothold in SDS. ${ }^{117}$ Ultimately, pleas for centralization overtook participatory democracy in the ideological contests of the 1968 convention.

The Radical Decentralist Project had an influential, albeit small, presence at the 1969 convention. The two resolutions that Bookchin wrote and Anarchos circulated did not argue for affinity groups as ends in themselves, but for non-hierarchical SDS chapters to organize around local student issues and a larger vision for revolution against capitalism, the state, and all human domination. ${ }^{118}$ Bookchin and Anarchos group were adept at distributing their printed materials across the convention space; in fact, not only did they hand out 2000 copies of Bookchin's 'Listen, Marxist!" pamphlet the previous day, they also convinced almost 250 delegates to 
support the Radical Decentralist Project over the perspectives of quarreling Marxist factions. This was still nowhere close to majority support at a convention with almost 2000 people, and so the anarchists were drowned out by the other factions: Progressive Labor had about 500 delegates, and the Weathermen and RYM shared about the same amount. ${ }^{119}$ The Radical Decentralist Project was politically significant not only for more than ten percent of the convention-goers, but also local and national journalists commenting mere months after the convention.

The anarchists at SDS attracted enough attention to draw the ire of rightwing journalists covering the convention's fallout. Thomas A. Lane, in the Ludington Daily News_a small Michigan newspaper — cherry-picked the Radical Decentralist Project's first resolution as proof that SDS's convention was filled with "the cadres of Jacobinism" who heralded a new Reign of Terror, repeating the political violence of Maximilien Robespierre, the Jacobin leader who guillotined political enemies during the French Revolution. ${ }^{120}$ Bookchin's resolution did connect the "radical Enlightenment" of the French Revolution in 1789 to the youth movement of the 1960s, but Lane erased nuance by calling Bookchin's writing "one of their resolutions," "their" meaning SDS as a whole. Although Lane singled out the document without understanding that it was a minority opinion at the convention, its reproduction in local news suggests that the document passed through enough hands to reach outside the convention. Lane referenced a report by Alice Widener, the conservative journalist whose columns appeared in over 100 newspapers nationwide. ${ }^{121}$ Widener's July 11 report on the SDS convention, in her self-published magazine U.S.A., quoted from the "Radical Decentralization [sic] Project, Resolution No. 1" as its first example of so-called dangerous ideas from SDS. Rep. John Ashbrook (R-Ohio) entered Widener's report on SDS into the Congressional record on July 22 , which indicates the national circulation of observations, albeit polemical and cherry-picked, linking SDS to anarchist organizing. ${ }^{122}$

Outside the circulation of right-wing hit-pieces, anarchists offered their own perspectives on the 1969 fallout. Chicago IWW member James Cain joined other countercultural anarchist SDS members to "rescue our revolutionary potential from the wreckage of SDS." He recounted this in a pamphlet in 1969 for Freedom Press called "Students for a Stalinist Society," in which Cain critiqued the PL and RYM factions for being dogmatic to the point that each labeled leftist critiques of their methods, such as those raised by countercultural anarchists, as anti-Communist. Cain's pamphlet was laced with invective, calling PL a group of "dull oxen" and pointing out the "power-lust of the fleshless faces" of RYM, but he adequately summarized the perspective of countercultural anarchists about the value of honest debates under participatory democracy. One of Cain's slogans for this reason was "Honesty is no threat to socialism."123 The pamphlet was significant not for its verdict about who or what was responsible for SDS's end, but for its argument about the formative influence of anarchism on SDS. Cain explained that SDS began with a civil rights coalition that included anarchists, and argued that while the liberals 
gave SDS its vision, "the Anarchists concocted the organizational conception (decentralization, local autonomy) and the style."124 Cain may have failed to give enough credit to the New Left students who authored the Port Huron Statement, but anarchists undoubtedly had a formative influence on SDS and its attempts to unite political and countercultural movements in a decentralized coalition. For Cain, SDS's failure was constructive: resistance by students and radicals had given them "time to expand and escalate both creative and classical approaches to revolutionary activity and organization." "125 These creative reinterpretations of classical revolutionary traditions were the defining characteristic of the New Left, and participatory democracy in SDS was designed for this creativity to expand.

But the fallout of SDS meant that absent from the national infrastructure connecting anarchists to New Left students, Bookchin's political project struggled to get off the ground. Anarchists in Madison, Wisconsin responded to the Anarchos Group's call for an organization to replace SDS with a gathering in Black River Falls, Wisconsin in September 1969. Ninety anarchists from Canada and the United States attended, but they could not agree whether to move forward with Bookchin's ecological vision or a Situationist strategy more akin to the Rosemonts' cultural analyses. Bookchin and anarchist Louise Crowley wrote a draft statement that attempted to combine the two perspectives, but they could not generate enough support, and ran a newsletter until December $1969 .{ }^{126}$ In the post-1968 moment, the counterculture declined because of law enforcement repression (particularly drug charges), the rise of the New Right, and stagflation in the 1970s — which disrupted "post-scarcity" visions of communal life. ${ }^{127}$ However, anarchism survived in the new environmentalist movement, such as the Abalone Alliance's consensus-based affinity groups against nuclear power through the 1970s and 1980s, which one scholar attributes to "anarchist-inspired prefigurative Utopian politics." 128 Anarchist inspirations also continued with the feminist and gay liberation movements of the 1970s: the Siren journal, published by women in Chicago, adopted anarcho-feminist ideals inspired by Emma Goldman's legacy, and the Gay Liberation Front adopted the ideal of participatory democracy. ${ }^{129}$

\section{Conclusion}

This essay has only scratched the surface of a deeper history of Students for a Democratic Society, which includes SDS's fractious relationship with the Black Power movement and the lingering sexism of male organizers excluding women in the student movement. Both of these themes can be explored from the framework this essay has proposed: that the rise-and-fall of the New Left in the 1960s was impacted by a growth in diverse ideological positions, all trying to formulate new answers to classic revolutionary dilemmas. That research focus is a needed corrective to the shift away from SDS-focused research in the scholarship, which explains why Kirkpatrick Sale's SDS, in 1973, is the only comprehensive history of the organization aside from a 2009 graphic novel containing participant histories and the stan- 
dard rise-and-fall narrative about PL and RYM. ${ }^{130}$ When historian Andrew Hunt surveyed the scholarship on 1960s social movements in 1999, he argued that "So much dissent and grass-roots resistance occurred outside of SDS's spotlight that it would be a terrible mistake to allow the group's evolution and decline to dictate the boundaries of sixties history and research."131 Surely "the Movement" cannot be reduced to SDS, as the organization was not even the most prominent agent of the movement against the Vietnam War, despite often receiving more press. With that said, SDS still deserves attention as a deeply informative case study of the larger divisions facing the Left in the sixties, such as the Old Left against New Left, Marxists against anarchists, and students against (or with) the counterculture. The Port Huron Statement has also been commemorated by historians 50 years after its publication, with one having called it "the most eloquent manifesto in the history of the American Left." 132 SDS's attempt to balance competing influences from anarchists, Marxists, and the student New Left made the organization the quintessential example of the 1960 s Movement's creative reinvention of radical traditions from the past. 


\section{NOTES}

${ }^{1}$ Jack A. Smith, 'SDS Theory: The "New Working Class Concept'—Students Would Set Up Cadre of Radical Organizers," National Guardian, April 22, 1967, 132-135 in Allan C. Brownfeld, The New Left: Memorandum, prepared for The Subcommittee to Investigate the Administration of the Internal Security Act and Other Internal Security Laws of the Committee on the Judiciary, United States Senate, Ninetieth Congress, Second Session, Washington: U.S. Government Printing Office, October 9, 1968.

${ }^{2}$ Mona Rocha, The Weatherwomen: Militant Feminists of the Weather Underground (Jefferson, NC: McFarland \& Company Inc., 2020); Ralph Young, Dissent: The History of an American Idea (New York, New York University Press, 2015); Blair Taylor, "Long Shadows of the New Left: From Students for a Democratic Society to Occupy Wall Street," in Revisiting the Sixties: Interdisciplinary Perspectives on America's Longest Decade, ed. Laura Bieger and Christian Lammert (Frankfurt: Campus Verlag, 2013); Jeremy Varon, Bringing the War Home: The Weather Underground, the Red Army Faction, and Revolutionary Violence in the Sixties and Seventies (Berkeley, CA: University of California Press, 2004).

3 Timothy Scott Brown, Sixties Europe (Cambridge, UK: Cambridge University Press, 2020), 64.

${ }^{4}$ Andrew Cornell, Unruly Equality: U.S. Anarchism in the Twentieth Century (Oakland, CA: University of California Press, 2016).

${ }^{5}$ Laurence Davis, "Social Anarchism or Lifestyle Anarchism: An Unhelpful Dichotomy," Anarchist Studies 18, no. 1 (2010): 63.

${ }^{6}$ Davis, "Social Anarchism or Lifestyle Anarchism," 74.

${ }^{7}$ John A. Moretta, "Political Hippies and Hip Politicos: Counterculture Alliance and Cultural Radicalism in 1960s Austin, Texas," Southwestern Historical Quarterly 123, no. 3 (January 2020).

${ }^{8}$ John A. Moretta, "Political Hippies and Hip Politicos: Counterculture Alliance and Cultural Radicalism in 1960s Austin, Texas," Southwestern Historical Quarterly 123:3, January 2020.

9 James J. Farrell, The Spirit of the Sixties: Making Postwar Radicalism (New York \& London: Routledge, 2013); Timothy Scott Brown, "The Sixties in the City: Avantgardes and Urban Rebels in New York, London, and West Berlin," Journal of Social History, 46, no. 4 (Summer 2013): 817-842.

10 This paper frequently references Kirkpatrick Sale's SDS because it is the earliest and only comprehensive history of the organization. Kirkpatrick Sale, SDS (New York City, NY: Vintage Books, 1973), 13.

${ }^{11}$ Peter Dreier, "Tom Hayden Always Rocked The Boat," The American Prospect, October 24, 2016, https:/ / prospect.org/economy/tom-hayden-always-rockedboat. 
${ }^{12}$ Sale, SDS, 14.

13 A 1967 exposé in Ramparts revealed that the National Student Association was secretly funded by the State Department and Central Intelligence Agency (CIA), but neither Haber nor even most NSA members knew this in 1961. Sale, SDS, 19. ${ }^{14}$ Sale, SDS, 25.

${ }^{15}$ Alice Wexler, Emma Goldman in Exile: From the Russian Revolution to the Spanish Civil War (Boston: Beacon Press, 1989).

${ }^{16}$ Brown, Sixties Europe, 43.

${ }^{17}$ Cornell, Unruly Equality, 256.

${ }^{18}$ Cornell, Unruly Equality, 256.

${ }^{19}$ Davis, "Social Anarchism or Lifestyle Anarchism."

${ }^{20}$ Cornell, Unruly Equality, 257.

21 Tom Hayden acknowledged this connection in a 2012 interview with Democracy Now! He explains, "So, we decided we would write this manifesto. And a professor named Arnold Kaufman suggested we use the term 'participatory democracy.' It also came from Ms. Ella Baker, who was the elder adviser to SNCC, who wanted the students in the South to have an autonomous movement, bottom-up movement, a self-determined movement, and not just follow the elder clergy." Tom Hayden, "SDS Founder, Veteran Activist Tom Hayden on Participatory Democracy from Port Huron to Occupy Wall Street," Democracy Now! April 13, 2012, https://www.democracynow.org/2012/4/13/sds_founder_veteran_activist_tom_hayden

${ }^{22}$ Francesca Polletta, "How Participatory Democracy Became White: Culture and Organizational Choice," Mobilization: An International Quarterly 10, no. 2 (June 2005): 2 .

${ }^{23}$ Gregory NeVala Calvert, Democracy from the Heart: Spiritual Values, Decentralism, and Democratic Idealism in the Movement of the 1960s (Eugene, OR: Communitas Press, 1991), 68.

${ }^{24}$ Mark Rudd, Underground: My Life with SDS and the Weathermen (New York: HarperCollins, 2009), 142.

${ }^{25}$ Harvey Pekar and Gary Dumm, Students for a Democratic Society: A Graphic History (New York: Farrar, Straus and Giroux - Macmillan, 2009), 9.

${ }^{26}$ Students for a Democratic Society, "The Port Huron Statement" (New York: Students for a Democratic Society, $2^{\text {nd }}$ ed., 1964), Introductory Note, http://www.progressivefox.com/misc_documents/PortHuronStatement.pdf. ${ }^{27}$ Paul Heideman, "Half the Way with Mao Zedong," Jacobin, May 23, 2018, https://www.jacobinmag.com/2018/05/half-the-way-with-mao-zedong. ${ }^{28}$ Ironically, anarchist scholars such as David Graeber have critiqued Students for a Democratic Society along the same line. On the Port Huron Statement and "participatory democracy": "One might see this as a very anarchistic vision, but 
SDS, as its inception, certainly did not...SDS was on paper a quite formal, topdown organization, with a central steering committee and meetings run according to Roberts Rules of Order.” David Graeber, “The Rebirth of Anarchism in North America, 1957-2007," Historia Actual Online (HAOL) 21(Winter 2010): 124. This paper qualifies Graeber's critique in two respects: first, Graeber overlooks the extent that anarchists tried to decentralize SDS from the inside, and second, SDS chapters tended to be more informally organized than the National Office.

${ }^{29}$ For more on students' two-pronged critique of capitalism and state socialism in the 1960s, see Brown, Sixties Europe, 64.

${ }^{30}$ Students for a Democratic Society National Convention, "Constitution," June 1962, https://www.sds-1960s.org/sds_wuo/sds_documents/sds_constitution.txt. ${ }^{31}$ James Miller, Democracy is in the Streets: From Port Huron to the Siege of Chicago (Cambridge, MA: Harvard University Press, 1994), 116.

32 Students for a Democratic Society, "The Port Huron Statement" (New York: Students for a Democratic Society, $2^{\text {nd }}$ ed., 1964), 6-8, http://www.progressivefox.com/misc_documents/PortHuronStatement.pdf

${ }^{33}$ Tony Thomas, "PL breaks with Maoism; brands China capitalist," The Militant, (September 24: 1971), 1, https://www.marxists.org/history/erol/1960-1970/militant-pl-china-1.pdf

${ }^{34}$ PL members are popularly remembered in oral histories of SDS as giving speeches with Mao's Little Red Book in their hands, but the Party had repudiated the Chinese government as a capitalist state in 1971. See Tony Thomas, "PL breaks with Maoism," 1.

35 Paul Saba, "The History of the Progressive Labor Party," Progressive Labor 10, no. 1(August-September 1975), https:/ /www.marxists.org/history/erol/19601970/plhistorynotes.htm.

${ }^{36}$ Saba, "The History of the Progressive Labor Party."

${ }^{37}$ Saba, "The History of the Progressive Labor Party."

38 The Sixties Project, "What is the May $2^{\text {nd }}$ Movement?" 1993, http://www2.iath.virginia.edu/sixties/HTML_docs/Resources/Primary/Manifestos/PL_M2d_manifesto.html; Sale, SDS, 65.

${ }^{39}$ May $2^{\text {nd }}$ Movement, "Dear Friend," Folder NY7, Digital Collections, Broadsides and Ephemera Collection, David M. Rubenstein Rare Book \& Manuscript Library, Duke University Libraries, 1965, https:// repository.duke.edu/dc/broadsides/bdsny 71543 .

40 Saba, "The History of the Progressive Labor Party."

${ }^{41}$ Sale, SDS, 66.

42 Sale, SDS, 66.

43 Sale, SDS, 93.

${ }^{44}$ For the Bread and Puppet Theater and pacifist anarchism, see Alan Filewod, 
Committing Theatre: Theatre Racialism and Political Intervention in Canada (Toronto: Between the Lines, 2011); for the Living Theatre and pacifist anarchism, see Richard Trousdell, "The Director as Pacifist-Anarchist: An Interview with Judith Malina," The Massachusetts Review 29, no. 1(Spring 1988): 22. For the Diggers in San Francisco and street theatre as a method of play, see Cornell, Unruly Equality, 252. 45 Tom Hayden, Hell No: The Forgotten Power of the Vietnam Peace Movement (New Haven, CT: Yale University Press, 2017), 26.

${ }^{46}$ Simon Hall, Peace and Freedom: The Civil Rights and Antiwar Movements in the 1960s (Philadelphia, PA: University of Pennsylvania Press, 2011), 25.

${ }^{47}$ Heideman, "Half the Way with Mao Zedong."

48 Sale, SDS, 96-97.

${ }^{49}$ Hall, Peace and Freedom, 24.

${ }^{50}$ Moretta, "Political Hippies," footnote 4.

${ }^{51}$ Quote by Jeff Shero, in Moretta, "Political Hippies," 289.

52 Sale, SDS, 188.

${ }^{53}$ Moretta, "Political Hippies," footnote 53.

54 The decision-making of the chapters is a hypothesis of this essay's author. For the dominance of PL in these chapters by 1965, see Rudd, Underground, 142.

${ }^{55}$ Students for a Democratic Society Constitution, June 1962, https:/ /www.sds1960s.org/sds_wuo/sds_documents/sds_constitution.txt.

${ }^{56}$ Pekar and Dumm, Students for a Democratic Society, 12.

${ }^{57}$ Sale, SDS, 113.

${ }^{58}$ Mitchell Hall, The Vietnam War, revised 2nd ed. (London: Pearson Education Limited, 2008), 46.

${ }^{59}$ Sale, SDS, 366.

${ }^{60}$ Rudd, Underground, 142.

${ }^{61}$ Sale, SDS, 108.

${ }^{62}$ Sale, SDS, 212.

${ }^{63}$ Carl Davidson, "Toward A Student Syndicalist Movement" (Position paper, Students for a Democratic Society Convention, Clear Lake, Iowa, August 1966), https:/ / libcom.org/library/toward-student-syndicalist-movement

${ }^{64}$ Rothbard reflected that in 1966 he "hailed the decisive turn" described here.

Murray Rothbard, The Betrayal of the American Right (Auburn, AL: Ludwig von Mises Institute, 2007), 195-196. The "I Hate the State" buttons at Clear Lake have been mentioned by more recent scholarship: see Karin Bauer, "From Protest to Resistance': Ulrike Meinhof and the Transatlantic Movement of Ideas," in Changing the World, Changing Oneself: Political Protest and Collective Identities in West Germany and the U.S. in the 1960s and 1970s, ed. Belinda Davis, Wilfried Mausbach, Martin Klimke, and Calra MacDougall (New York: Berghahn Books, 2010), 173. 
${ }^{65}$ Carl Davidson, "Toward A Student Syndicalist Movement" for more on Rebel Worker, see Brown, "The Sixties in the City."

${ }^{66}$ Isaacson, The Ballerina and the Bull, n.p., Google Books.

${ }^{67}$ Melvyn Dubofsky, "Industrial Workers of the World," Encyclopedia of Chicago, Chicago Historical Society, 2005, http:/ / www.encyclopedia.chicagohistory.org/pages/640.html.

${ }^{68}$ Davidson lamented the "prairie power" students as the un-intellectual "shock troops" of SDS. See Sale, SDS, 235.

${ }^{69}$ Sale, SDS, 188.

70 "We took the name Rebel Worker from an old Wobbly paper, circa 1919. For us it signified not only the worker as rebel, but also - and no less important - rebellion against work," said Franklin Rosemont. "The Rebel Worker-No. 3," Lorne Bair Rare Books, Manuscripts \& Ephemera, Winter 1965, date accessed October 11, 2020, https:/ /www.lornebair.com/pages/books/38664/franklinrosemont/the-rebel-worker-no-3-winter-1965.

${ }^{71}$ The Rebel Worker was the name for the Wobblies' official journal in 1919, published in New York, alongside The One Big Union Monthly in Chicago. J. Castell Hopkins, The Canadian Annual Review of Public Affairs (Toronto: The Canadian Annual Review, Limited, 1919), 450. https://electriccanadian.com/history/annual/canadianannual19.pdf.

${ }^{72}$ Dick Hebdige, Subculture: The Meaning of Style (London: Methuen \& Co. Ltd, Routledge, 1979), 105.

${ }^{73}$ Penelope Rosemont, "My Life in SDS," in Pekar and Dumm, Students for a Democratic Society, 77.

${ }^{74}$ Ron Sakolsky, "The Surrealist Adventure and the Poetry of Direct Action: Passionate Encounters Between the Chicago Surrealist Group, the Wobblies and Earth First!" The Journal of Aesthetics \& Protest, Issue 8 (Winter 2011/2012):

https://joaap.org/issue8/Sakolsky_surrealists.htm.

${ }^{75}$ Franklin Rosemont, "Mods, Rockers and the Revolution," Rebel Worker no.

3(March 1965): http:/ / history-is-made-at-night.blogspot.com/2009/04/franklinrosemont-mods-rockers-and.html.

${ }^{76}$ Rosemont, "My Life in SDS," 78.

${ }^{77}$ Alexander Berkman, Prison Memoirs of an Anarchist (New York: Mother Earth

Publishing Association, 1912), 150.

${ }^{78}$ Rosemont, "My Life in SDS," 79-80, 88.

${ }^{79}$ Osha Neumann, Up Against the Wall Motherf**ker: A Memoir of the '60s, With

Notes for Next Time (New York: Seven Stories Press, 2008), 7.

${ }^{80}$ Neumann, Up Against the Wall Motherf**ker, 54.

${ }^{81}$ Neumann, Up Against the Wall Motherf**ker, 7

82 Ben Morea, interview with the author, email on February 10, 2020. 
83 Peter Kropotkin, Mutual Aid: A Factor of Evolution, 1902, https:/ / theanarchistlibrary.org/library/petr-kropotkin-mutual-aid-a-factor-of-evolution. Mutual aid has also been revived in response to the COVID-19 epidemic by many groups, anarchist or non-affiliated, across the country. Lucy Diavolo, "People Are Fighting the Coronavirus With Mutual Aid Efforts to Help Each Other," Teen Vogue, March 16, 2020, https:/ /www.teenvogue.com/story/people-fighting-coronavirus-mutual-aid-efforts-help-each-other.

${ }^{84}$ Black Mask frequently called the church "St. Marx" in flyers; this harkened to the nickname that quintessential New York anarchist Emma Goldman gave St. Marks Street, "Hail Marx Place.” For Black Mask and squatters, see UAW/MF, "Extrapolate From The Following," in Up Against The Wall Motherfucker! An anthology of rants, posters and more (Melbourne, Australia: Homebrew Publications, Melbourne University, 2007), 48. For the "free store" and donations outside of St. Marks Church, see Ada Calhoun, St. Marks Is Dead: The Many Lives of America's Hippest Street (New York: W.W. Norton \& Company, November 2, 2015).

${ }^{85}$ Title page of Black Mask no. 1, November 1966, in Black Mask \& Up Against the Wall Motherfucker: The Incomplete Works of Ron Habne, Ben Morea, and the Black Mask Group (Oakland, CA: PM Press, 2011), 4

${ }^{86}$ Ben Morea, letter to Louise Crowley (November 1966), in Black Mask \& Up Against the Wall Motherfucker, 6-7.

${ }^{87}$ Janet Biehl, Ecology or Catastrophe: The Life of Murray Bookechin (Oxford, UK: Oxford University Press, 2015), footnote 50, 120.

${ }^{88}$ Ben Morea, "Brothers, Sisters, Comrades \& Friends," in Black Mask \& Up Against the Wall Motherfucker, 86.

${ }^{89}$ Newsreel, “Garbage NY Newsreel/Motherfuckers, 1968,” You'Tube video, January 31, 2014, accessed February 8, 2020,

https://www.youtube.com/watch?v=KtX8IEWabTY.

${ }^{90}$ Conor Hannan, "We have our own struggle': Up Against the Wall Motherfucker and the avant-garde of community action, the Lower East Side, 1968," The Sixties 9 no. 1 (2016), 123.

${ }^{91}$ This is the group's well-known appellation. See Timothy Scott Brown, "The Sixties in the City: Avant-gardes and Urban Rebels in New York, London, and West Berlin," Journal of Social History 46, (Summer 2013), 827.

${ }^{2}$ Neumann, Up Against the Wall Motherf**ker, 88.

${ }^{93}$ Neumann, Up Against the Wall Motherf**ker, 88.

${ }^{94}$ Ben Morea, interview with Iain McIntyre in Black Mask \& Up Against the Wall Motherfucker, 157.

95 This is the group's well-known appellation. See Timothy Scott Brown, "The Sixties in the City: Avant-gardes and Urban Rebels in New York, London, and West Berlin," Journal of Social History 46, Summer 2013, pg. 827. 


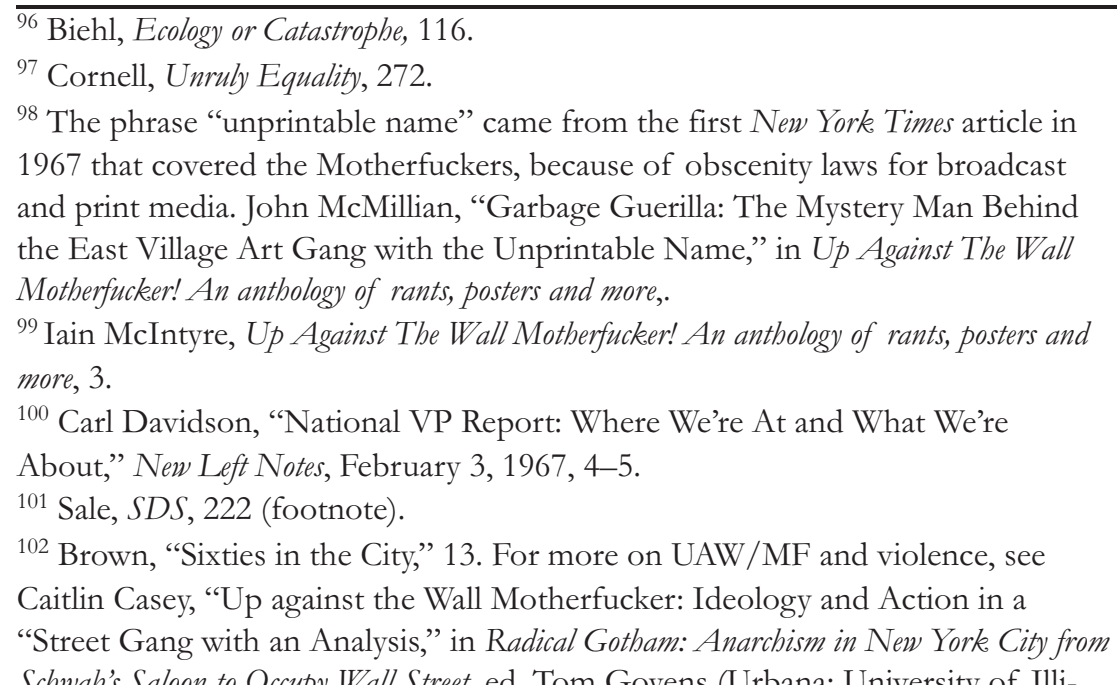
Schwab's Saloon to Occupy Wall Street, ed. Tom Goyens (Urbana: University of Illinois Press, 2017).

${ }^{103}$ UAW/MF, “Chapter Report on the S.D.S. Regional Council of March 10," in Black Mask \& Up Against the Wall Motherfucker, 141.

${ }^{104}$ Neumann, Up Against the Wall Motherf**ker, 88.

105 William L. O'Neill, Coming Apart: An Informal History of America in the 1960s (New York \& Toronto: Times Books, Random House Inc., 1971), Internet Archive.

${ }^{106}$ Jim O'Brien, “The Student Movement and the New Left, 1960-1969 (Part III)," Society for U.S. Intellectual History, March 14, 2017, https:/ / susih.org/2017/03/jim-obrien-the-student-movement-and-the-new-left-19601969-part-iii/.

107 Sale, SDS, 247.

108 O'Brien, "The Student Movement and the New Left."

${ }^{109}$ James Cain, "Students for a Stalinist Society" (London, UK: Freedom Press, 1969), Pg. 5, https://theanarchistlibrary.org/library/james-w-cain-students-for-astalinist-society.pdf.

${ }^{110}$ Sale, SDS, 249.

111 O'Brien, "The Student Movement and the New Left."

112 Sale, SDS, 271.

113 Murray Bookchin, "Listen, Marxist!” brochure published by Anarchos for the SDS Conference, 1969, https://www.marxists.org/archive/bookchin/1969/listen-marxist.htm\#h5.

114 Biehl, Ecology or Catastrophe, 123.

${ }^{115}$ Pekar and Dumm, Students for a Democratic Society, 43. 
${ }^{116}$ Biehl, Ecology or Catastrophe, 124.

117 Paul Goodman, "The Black Flag of Anarchism," The New York Times Magazine, July 14, 1968, http://www.ditext.com/goodman/flag.html.

${ }^{118}$ Kenneth Heineman, Campus Wars: The Peace Movement at American State Universities in the Vietnam Era (New York: New York University Press, 1992), 199, Google Books.

${ }^{119}$ Sale states that "The NO caucus decided to concentrate its forces on reorganizing the national structure along the lines of a centralized 'cadre' approach, which it hoped would put enough power in the hands of the traditional SDSers to either eliminate or curtail PL influence in the organization." Sale, SDS, 315.

${ }^{120}$ Murray Bookchin, "Toward a Post-Scarcity Society: The American Perspective and S.D.S.," Resolution No. 1, Platform of the Radical Decentralist Project at the last SDS Conference, May 1969, https:/ / omeka.library.kent.edu/special-collections/mirador-viewer?item_id=6443\&count $=10$.

${ }^{121}$ Andrew Cornell, “"For a World Without Oppressors:' U.S. Anarchism from the Palmer Raids to the Sixties," (PhD Dissertation in American Studies, New York University, 2011).

122 Thomas A. Lane, “SDS Honors Jacobin Heritage," Ludington Daily News, November 11, 1969, 3. Google News Archive.

${ }^{123}$ Mrs. Widener was a self-syndicated columnist whose work appeared in more than 100 newspapers in the United States. Her articles appeared in various publications, including Life, The Atlantic Monthly, Barron's National Business, and Financial Weekly. "Alice Widener," Obituary, The New York Times, January 31, 1985, B12. TimesMachine.

${ }^{124}$ Hon. John M. Ashbrook of Ohio in the House of Representatives, "Join the Conspiracy," July 22, 1969, Congressional Record: Proceedings and Debates of the $91^{\text {st }}$ Congress, First Session, Volume 115_Part 15, July 15, 1969 to July 25, 1969. Google Books.

${ }^{125}$ Cain, "Students for a Stalinist Society," 4.

${ }^{126}$ Cain, "Students for a Stalinist Society," 3.

${ }^{127}$ Cain, "Students for a Stalinist Society," 4.

${ }^{128}$ Cornell, Unruly Equality, 275.

${ }^{129}$ Blake Slonecker, "The Counterculture of the 1960s and 1970s," Oxford Research Encyclopedia of American History, June 2017.

${ }^{130}$ Laurence Davis, "Abalone Alliance," The International Encyclopedia of Revolution and Protest, April 20, 2009. Wiley Online Library.

131 Cornell, Unruly Equality, 275.

${ }^{132}$ Pekar and Dumm, Students for a Democratic Society.

133 Andrew Hunt, “'When Did The Sixties Happen?' Searching For New Directions," Journal of Social History 33, no. 1 (Fall 1999): 148. 
${ }^{134}$ Michael Kazin, “The Port Huron Statement at Fifty,” Dissent, Spring 2012, https://www.dissentmagazine.org/article/the-port-huron-statement-at-fifty. 